\title{
TEACHING READING USING AUTENTIC MATERIALS
}

\author{
Mahendra Puji Permana Aji \\ Engish Education Department, Nusantara PGRI University, Kediri, Indonesia \\ email:inbox@mahendrapuji.web.id
}

\begin{abstract}
Reading a foreign written text may arise many problems to the students. During teaching learning process, most of the students think that it is difficult to master reading skill because when they discuss about reading a text they usually get bored. The material becomes big problem because the text is too long and it uses difficult vocabularies. Teaching reading can means the activity of language by encouraging skimming, scanning, predicting, and activating schemata. There are three steps of teaching reading, they are pre reading, whilst reading and post reading. In teaching reading there are three process of reading, they are top-down processing, bottom-up processing and interactive reading. Reading material that can be used is authentic material, authentic material is materials written or spoken language that is produced in real communication and not for purpose of language teaching for example newspapers, magazines, TV programs, movies, songs and literature. This is a qualitative research. The data was obtained from observation, interview and documentation. The writer collects the data by preparing the instrument, observing the reading class, interviewing the teacher and collecting written document used. The result of the research shows that the materials used by the teacher to teach reading are articles taken from some foreign magazines and online news from the internet because it contains materials about many things related to real life which would make students interested in reading the text. So it can be concluded that the teaching learning process of reading class runs effectively. The teacher uses steps that make the students understand the materials easily.
\end{abstract}

Keywords: Authentic material, Reading, Teaching

\section{INTRODUCTION}

Mastering the four language skills and understanding the components of language are very important to the students in learning English.When studying English the students must master all skills. One of the skills that must be learn is reading. Due to the fact that reading skill is very important for students to master, they should get information from English material in the written text. During teaching learning process, most of the students think that it is difficult to master reading skill because when they discuss about reading a certain text they usually get bored, in this case because of lack of vocabulary and less motivation. Many 
efforts have been done to solve these problems, but the results are still under expectation.

The problems above may be caused by several reasons; could be the teacher, could be the techniques or the materials. The material becomes big problem because the text is too long and it uses difficult vocabularies. Furthermore, the text is designed for language learning purposes, so it has nothing to do with their lives. The language in text is specific and concentrates on academic aspects containing a series texts that have been modified. They include perfectly formed sentences, a question using a grammatical structure, gets a full answer, and repetition of structures. The use of nature of language and structure make them very confused and dislike the materials right after they read. The reading text is unlike anything that the learner found in the real world and often it does not reflect how the language is really used. In addition, the topics of the text are often out of date. As the result, they have difficulties in comprehending the text.

To overcome this problem, many ways to improve reading ability have been done by the teacher such as using different text book from different author and selecting interesting topics from many text books. However, the students' reading comprehension is still disappointing. In order to solve this problem, the teacher uses different materials. The material that can be used is authentic materials.

Authentic texts has been defined as "....real-life texts, not written for pedagogic purposes" (Wallace 1992: 145). The source of authentic materials that can be used in the classroom can come from anywhere, but the most common are news papers, magazines, TV programs, movies, songs, literature and internet. Authentic materials help students provide additional information that can link between the classroom and the outside world. If the classroom is not a real-life situation, authentic materials still have a very important rules in it. The authentic materials enable learners to interact with the real language and content rather than the form. It means the texts relate with students' daily lives such as health, love, education, jobs, movies etc. Those make students more interested in reading the text. It supported by Nuttal (1996: 172) "Authentic texts can be motivating because they are proof that the language is used for real-life purposes by real people". Those are the reasons that authentic materials can improve students' comprehension. By introducing authentic material, it is hoped that the learners 
| Volume: 1 | Number: 2 | October 2016 | ISSN: 2503 - 4405|

will not focused on the formal language of classroom but the real world and language how it is really used. Here, the function of teacher are to prepare students, giving the awareness, and to understand how the language is actually used.

\section{IMPORTANT FACTORS IN CHOOSING AUTHENTIC READING MATERIALS}

Four types of authenticity within the classroom have been identified. They are : authenticity of the texts which we may use as input data for our students, authenticity of the learners' own interpretations of such texts, authenticity of tasks conducive to language learning, authenticity of the actual social situation of the classroom language. (Breen 1995: 61). Widdowson has a process-orientated view of authenticity, making a distinction between authentic and genuine. Genuine is an example of native speaker language, while authentic is a native speaker response (it can also include the response the writer intended upon when writing the text.) "The language presented to them may be a genuine record of native speaker behavior, genuine, that is to say, as textual data, but to the extent that it does not engage native speaker response it cannot be realized as authentic discourse." (Widdowson 1990: 45).

Therefore authenticity considered to be the interaction between the reader and the text. Reading is considered to be an ongoing interaction, going beyond the physical context of the text, looking for meaning as well as processing information.

\section{THE USE OF AUTHENTIC MATERIAL IN TEACHING READING}

One of the main ideas of using authentic materials in the classroom is to expose the learner to as much real language as possible. Even if the classroom is not a real-life situation, authentic materials have a very important place within it. It has been argued that by taking a text out of its original context, it loses it authenticity: "As soon as texts, whatever their original purpose, are brought into classrooms for pedagogic purposes they have, arguably, lost authenticity." (Wallace 1992: 79). The learner is still exposed to real discourse and not the artificial language of course textbooks, which tend not to contain any incidental or improper examples. They also tend to reflect the current teaching trend. Authentic materials also give the reader the opportunity to gain real information and know 
| Volume: 1 | Number: 2 | October 2016 | ISSN: 2503 - 4405|

what is going on in the world around them. More times than not, they have something to say, be it giving information, a review. They also produce a sense of achievement. Extracting real information from a real text in a new/different language can be extremely motivating, therefore increasing students' motivation for learning by exposing them to real language (Guariento \& Morley 2001). They also reflect the changes in language use, (again something that does not occur in textbooks, which become very dated, very quickly) as well as giving the learner the proof that the language is real and not only studied in the classroom: "Authentic texts can be motivating because they are proof that the language is used for reallife purposes by real people." (Nuttall in Berardo 1996: 172)

The wide variety of different types of text means that it is easier to find something that will interest the learner and may even encourage further reading or reading for pleasure.

An advantage of taking a complete newspaper or magazine into classroom, rather than photocopies of an article, is that students can actually choose what they want to read. The more the learner reads, the better a reader they will become to help the students, not only improves his language level but also confidence. If the text interests the learner it can also be related to his own experiences. One of the aims of authentic materials is to help the student react in the same way L1 speakers react in their first language. Learners who live in the target language environment, once outside of the classroom will encounter a variety of situations in which different reading purposes/skills are required. We can claim that learners are being exposed to real language and they feel that they are learning the real language.

\section{METHOD}

\section{Research Design}

This is a descriptive qualitative research. The description involves the material, the technique, and the evaluation used by the teacher. It is stressed on the process of teaching and learning reading. It need some instruments to get the data, they are: 1) Observation, It means that the writer should observe the object of the study directly to find out the data that is necessary for the study. In this case, the writer used check list to get the data of teaching and learning process of 
| Volume: 1 | Number: 2 | October 2016 | ISSN: 2503 - 4405|

reading using authentic material. 2.) Interview, the writer tries to find out the data based on the interview with the teacher. The interview was done by giving some questions to the teacher concerning with the way of teacher's teaching. 3.) Documentation, documentation here refers to text books, syllabus, teaching materials and forms of evaluation used by the teacher. The subject of the research of this study is the teacher that teaching English subject at SMPN 1 Prambon Nganjuk.

\section{Research Procedure}

At this part, the procedure of research is divided into 2 steps as follows:

1. Preliminary Survey

In this step, the researcher do preliminary survey by introducing the authentic materials while teaching reading to the second grade students.

2. Collecting Data

In collecting data, the writer makes observation to differ between authentic material and non-authentic material and evaluated the usage of them in the classroom. It is necessary to know whether teaching reading using materials appropriate to the students.

3. Analyzing Data.

The tecnique of data analysis is describing the data collected from the class observation during the teaching learning process and the interview with the English teacher.

\section{FINDING AND DISCUSSION}

\section{The Material}

To teach reading the teacher designed material in a power point presentation by put some article taken from foreign magazine and news on line from internet. The goals of material when the writer did observation are reading for specific information, reading for gist and discussing the habits. The material used by the teacher was descriptive text discussing topic about describing place such as school, home or favorite place that ever visited by the students; letters ; and advertisements. 
The teaching learning process was held in the laboratory, when learning the English language the students move into the language lab. The teacher used computer and LCD projector to teach. The teacher opened power point files had been prepared before and showed the material to be taught to the students. If there were difficult words or new vocabularies, the students looked in dictionary program in the computer and the program was completed how to pronounce the words in English properly so the students could read the meaning of difficult words in English form with the correct pronunciation. It was intended to make effectiveness and to make teaching learning process become real life situation.

\section{The Technique}

To make the teaching and learning activities successful, the teacher designed the technique in teaching learning process. The technique usually used by the teacher is described as follows:

a. First Meeting

1) Pre reading activities

The teacher opened the class by greeting. Then she asked about the conditions of the students that did not attend the class last week because of sick. After that, the teacher showed the students some letters that she bought from home. The teacher asked the students whether they ever got a letter from someone they know. She did this as a part of leading question that hoped to get student's interest and attention to the topic.

2) Whilst reading activities

After giving leading question, the teacher asked the students to be quite and silent. She would read a letter that she brings. Then, the teacher asked the students to re-read aloud the letter after her. Line by line she read and the students re-read the letter. After that, the teacher and the student discussed the part of letter that they have read. Then, the teacher gave a short games questioner to the students. The questions were about the main idea of the letter, the sender and the receiver of the letter. The students who knew the answer could raise their hand and answer the question. This made the class more interactive and interesting. 
3) Post reading activities

In post reading activity, the teacher asked the students about their difficulties in understanding the text in form of letter. Then, together, the students and the teacher made some summaries about the topic that they have discussed. Before ending the class, the teacher gave a home work to the students to find a letter from internet about certain topics.

\section{DISCUSSION}

The teacher tries hard to prepare the material before teaching reading. The materials are taken from some authentic sources such as abroad magazine and authentic material from the internet. She chooses topics that are familiar for the students. To teach reading the teacher uses three steps of teaching reading, they are pre reading, whilst reading, and post reading.

In pre reading, the teacher tries to make the students interested in reading class by asking the students to have a talk before starting the lesson to make closer situation. The teacher also gives leading questions it's good for the students to bring them to the topic that will be discussed.

In whilst reading, the teacher gives discussion topic before reading to the material. From this stage the students can have description of the material that they will read. Then the teacher provides materials to the students, also introduces difficult words or new vocabularies in the material that will be discussed by the students. It is important to build the students' vocabularies and help them to understand the material. In reading activity, the students read the material that is authentic text taken from abroad magazine then answer the question, the teacher check them, then the teacher and the students check together about the information of the material.

In post reading, consist of either any of the related activities or communicative activities. While the goal is to get the students to find out the information from the texts given. The activities are giving opinion, summarizing the content of the text, rearranging of the jumble sentence, and the teacher asking them to give their own opinion about the topic to know how far they understand the material give. 
| Volume: 1 | Number: 2 | October 2016 | ISSN: 2503 - 4405|

Then for the evaluation the teacher gives feedback to the students. It's important in order they have motivation in reading class. She also gives assessment to the students from some aspect, they are from test, assignment, attitude of the students and also from individual worksheet. So she gives the final score that come from many aspects of the students.

\section{CONCLUSIONS}

Based onwhat has ben discussed in the previous chapter,it can be concluded that: 1)The teacher of the second year students of SMPN 1 Prambon Nganjuk uses authentic materials to teach reading. The materials are taken from abroad magazine and internet. The teacher chooses the topics that familiar for the students. 2)The teaching learning process of reading is held in the language laboratory. The teacher uses some media in teaching reading, they are computer, laptop, LCD projector. The materials have saved in the Microsoft power point and Microsoft word programs in the computer. The computer is also having dictionary program with pronunciation program. If the students find difficult words and new vocabularies, they can find the meaning and how to pronounce them in that dictionary program.3) The teacher applies simple steps in teaching reading in the classroom they are pre reading, whilst reading and post reading. The teaching learning process of reading class runs effectively. The teacher uses steps that make the students understand the materials easily. But she does not give more chances to the students to tell what they get from the materials that they read. 4) The lecturer gives assessments to the students from the result of the students' test, students' assignments, and the students' attitude, interest and motivation in teaching learning process. The teacher also gives individual worksheet to evaluate the students. Individual worksheet is given in certain time. 5) The students follow the reading class regularly. They give attention and do the work that the lecturer asks.

\section{REFERENCES}

Anderson. J. Charles\&Bachman Lyle F. 2000. Assessing Reading. United Kingdom: Cambridge University Press. 
| Volume: 1 | Number: 2 | October 2016 | ISSN: 2503 - 4405|

Anderson. J. Charles. 1999. Exploring Second Language Reading: Issues and Strategies. Canada: Brigham young University.

Berardo, Sacha Anthony. 2006. The Use of Authentic Materials in the Teaching of Reading in The Reading MatrixJournal 6. Pp 60-67

Brown, Douglas. 2001. Teaching by Principles: An Interactive Approach to language Pedagogy. Second Edition. San Francisco State University : Longman.

Harmer, Jeremy. 1991. The Practise of English Language Teaching.London and New York: Longman Group.

Hudson, Thom. 2007. Teaching Second Language Reading. New York: Oxford University Press.

Peacock, M. (1997) The Effect of Authentic Materials on the Motivation of EFL Learners in English Language Teaching Journal 51, pp 2

Stoller, Fredricka L\&Grabe, William. 2002. Teaching and Researching Reading: Applied Linguistics in Action Series. Great Britain: Longman Group.

Ur, Penny. 1996. A Course in Language Teaching. Great Britain: Cambridge University Press. 